\title{
Chronic kidney disease progression in a large prevention program in Colombia: A cohort study
}

\author{
Mauricio Sanabria ${ }^{1 *}$, Diana Espinosa ${ }^{2}$, Luz A. Quintero², Izcay Ronderos ${ }^{3}$, Jasmin Vesga ${ }^{1}$, Delia Perea ${ }^{3}$, \\ Nelcy Rodriguez ${ }^{4}$, Carlos J. Rincon ${ }^{4}$, Lina J. Herrera ${ }^{4}$, and Leyder Corzo ${ }^{5}$ \\ ${ }^{1}$ Baxter Renal Care Services Latinoamerica, Bogota; ${ }^{2}$ Compensar EPS, Bogota; ${ }^{3}$ Baxter Renal Care Services Colombia, Clinica de Salud Renal, \\ Bogota; ${ }^{4}$ Pontificia Universidad Javeriana, Departamento de Epidemiologia y bioestadística, Facultad de medicina, Bogota; ${ }^{5}$ Baxter Renal Care \\ Services Colombia, Instituto Nacional del Riñon, Bogota, Colombia
}

\begin{abstract}
Background: Estimating morbidity outcomes and the rate of progression of chronic kidney disease (CKD) patients is of great importance for the health systems. Objective: The objective of this study is to estimate the incidence of dialysis initiation and the rate of CKD progression in 2 years follow-up and identify factors associated with dialysis starts. Methods: A retrospective cohort study of adult with diagnosed CKD stages-G3, G4 (estimated glomerular filtration rate between 60 and $15 \mathrm{~m} / \mathrm{min} / 1.73 \mathrm{~m}^{2}$ ) enrolled into a CKD prevention program in Bogotá-Colombia, since January 1, 2016, to June 30, 2017, with follow-up until June 30, 2019. Cohort's outcomes were arrival to dialysis and stage G5, dropout of the program, hospitalization, and mortality. Repeated measurements of the estimation of glomerular filtration rate (eGFR) allowed us to estimate the change over time in 4-month periods using a mixed-effects model. An Extended Cox model was adjusted for the time to start dialysis. Results: One thousand four hundred forty-eight patients were included in the analysis; the incidence rate of dialysis initiation was 2.1 events per 100 patients-year (95\% Cl: 1.52 .7 ). The mean of eGFR variation was $+1.1 \mathrm{ml} / \mathrm{min} / 1.73 \mathrm{~m}^{2} /$ year; and for diabetics was $-1.0 \mathrm{~m} / \mathrm{min} / \mathrm{m}^{2} /$ year. Being diabetic and having poorly controlled hypertension were significant risk factors for time to dialysis initiation. Conclusion: The incidence rates of dialysis initiation, dropout, and hospitalization are outcomes of significant interest in a CKD prevention program. Being diabetic and poor blood pressure control are risk factors for a more rapid progression to dialysis.
\end{abstract}

Key words: Chronic kidney disease. Progression. Prevention. Predialysis. Kidney failure.

\section{Programa de prevención de la progresión de la enfermedad renal crónica en Colombia: un estudio de cohorte}

\section{Resumen}

Antecedentes: Estimar los resultados de morbilidad y la tasa de progresión de los pacientes con enfermedad renal crónica (ERC) es de gran importancia para los sistemas de salud. Objetivo: El objetivo de este estudio es estimar la incidencia de inicio de diálisis y la velocidad de progresión de la ERC en dos años de seguimiento, e identificar factores asociados con el inicio de diálisis. Métodos: Estudio de cohorte retrospectiva en adultos con diagnóstico de ERC estadios-G3, G4 (Tasa de Filtración Glomerular estimada entre 60 y $15 \mathrm{ml} / \mathrm{min} / 1.73 \mathrm{~m}^{2}$ ) inscritos en un programa de prevención de ERC en

\section{Correspondence:}

*Mauricio Sanabria

E-mail: mauricio_sanabria@baxter.com
Date of reception: 18-11-2020

Date of acceptance: 21-03-2021

DOI: 10.24875/NEFRO.20000055
Disponible en internet: 18-06-2021

Nefro Latinoam. 2021;18:41-49 www.nefrologialatinoamericana.com

2444-9032/( 2021 Sociedad Latinoamericana de Nefrología e Hipertensión. Published by Permanyer. This is an open access article under the CC BY-NC-ND license (http://creativecommons.org/licenses/by-nc-nd/4.0/). 
Nefro Latinoam. 2021;18

Bogotá-Colombia, desde el 1 de enero de 2016 al 30 de junio de 2017 con seguimiento hasta el 30 de junio de 2019. Resultados de la cohorte fueron llegada a diálisis y a estadio G5, abandono del programa, hospitalización y mortalidad. Las mediciones repetidas de la estimación de la tasa de filtración glomerular (TFGe) nos permitieron estimar el cambio a lo largo del tiempo en períodos de cuatro meses utilizando un modelo de efectos mixtos. Se ajustó un modelo de Cox extendido para el tiempo al inicio de diálisis. Resultados: Se incluyeron 1448 pacientes en el análisis; la tasa de incidencia de inicio de diálisis fue de 2.1 eventos por 100 pacientes-año, (IC 95\%: 1.5 2.7). La media de la variación de la TFGe fue de $+1.1 \mathrm{ml} / \mathrm{min} / 1.73 \mathrm{~m}^{2}$ por año; y para los diabéticos fue de $-1.0 \mathrm{ml} / \mathrm{min} / \mathrm{m}^{2}$ por año. Ser diabético y tener una hipertensión mal controlada fueron factores de riesgo importantes para el tiempo hasta el inicio de la diálisis. Conclusión: Las tasas de inicio de diálisis, salida del programa y hospitalización son desenlaces de un interés muy significativo en un programa de prevención secundaria de la ERC. Ser diabético y el control deficiente de la presión arterial son factores de riesgo para una progresión más rápida a diálisis.

Palabras clave: Enfermedad renal crónica. Progresión. Prevención. Pre-diálisis. Falla renal.

\section{Introduction}

Chronic kidney disease (CKD) is a broad term representing a large umbrella under which various disorders that affect the structure and function of the kidneys are grouped ${ }^{1}$. The characteristics and risk factors of CKD progression were established since the end of the last century ${ }^{2}$. After this, a whole body of evidence about CKD was redefined and organized in the clinical guidelines for the evaluation, management, and treatment of patients with CKD, which today serve as a guide for the care of these patients ${ }^{3}$. Recently a KDIGO consensus conference updated and harmonized the nomenclature for kidney disease, which allows different actors of the health systems to speak the same language ${ }^{4}$.

In parallel to these advances in the understanding of this disease, health systems worldwide have developed strategies to alleviate the burden of this entity on populations ${ }^{5}$.

Part of the CKD burden lies in its characteristic of progressive entity up to kidney failure (KF). This phenomenon has been well studied and shows significant variability between the different subpopulations ${ }^{6-9}$. Conventionally, the rate of CKD progression has been evaluated with linear regression methods of multiple estimates over time of glomerular filtration rate (eGFR) ${ }^{10-12}$.

It should be noted that the linear progression paradigm has been challenged by several studies showing that progression patterns often differ from linearity ${ }^{13,14}$. These understandings have favored the use of different statistical models in the way of knowing the influence that multiple predictive variables may have on outcomes such as the speed of progression or initiation of kidney replacement therapy (KRT) ${ }^{15-18}$.

In Colombia, a CKD prevention program was established to integrate the primary and specialized levels of care between the health-promoting entity Compensar ${ }^{\circledR}$ and the specialized renal care clinic Baxter Renal Care Service (RCS) ${ }^{\circledR}$. The program's objective was to detect patients with CKD stages G3 and G4 early, systematically intervene them, slow down the progression of $\mathrm{CKD}$, and ensure a planned start of dialysis ${ }^{19}$.

The objective of this study is to estimate the incidence of dialysis initiation and the speed of CKD progression and identify factors associated with time to dialysis starts.

\section{Material and methods}

\section{Study design and patients}

A retrospective, cohort study of patients undergoing CKD prevention program in Bogota was conducted between January 1, 2016, and June 30, 2017, with follow-up until June 30, 2019, at Baxter Renal Care Services $^{\circledR}$ (RCS) network. Patients were older than 18 years of age, with a diagnosis of CKD stages G3 or G4 (glomerular filtration rates between 60 and $15 \mathrm{ml} / \mathrm{min} / 1.73 \mathrm{~m}^{2}$ ) included on the health-promoting entity Compensar ${ }^{\circledR}$ (patients with CKD stages G2 or G1 are not included). To be part of the program, two eGFRs $<60 \mathrm{ml} / \mathrm{min} / 1.73 \mathrm{~m}^{2}$ and a CKD diagnosis made by a nephrologist were required; were excluded from the analysis patients with Charlson comorbidity index $>8$ and have $<90$ days in the prevention program. The GFR estimation was based on repeated measures of serum creatinine according to the CKD-EPI equation (during the follow-up were required at least three eGFR-CKD EPI measurements for progression estimation). The study protocol was approved by the clinical research ethics committee of Fundación Cardioinfantil, Bogotá (July 31, 2019, Minute, item number 025), who exempted the use of informed consent as this study 


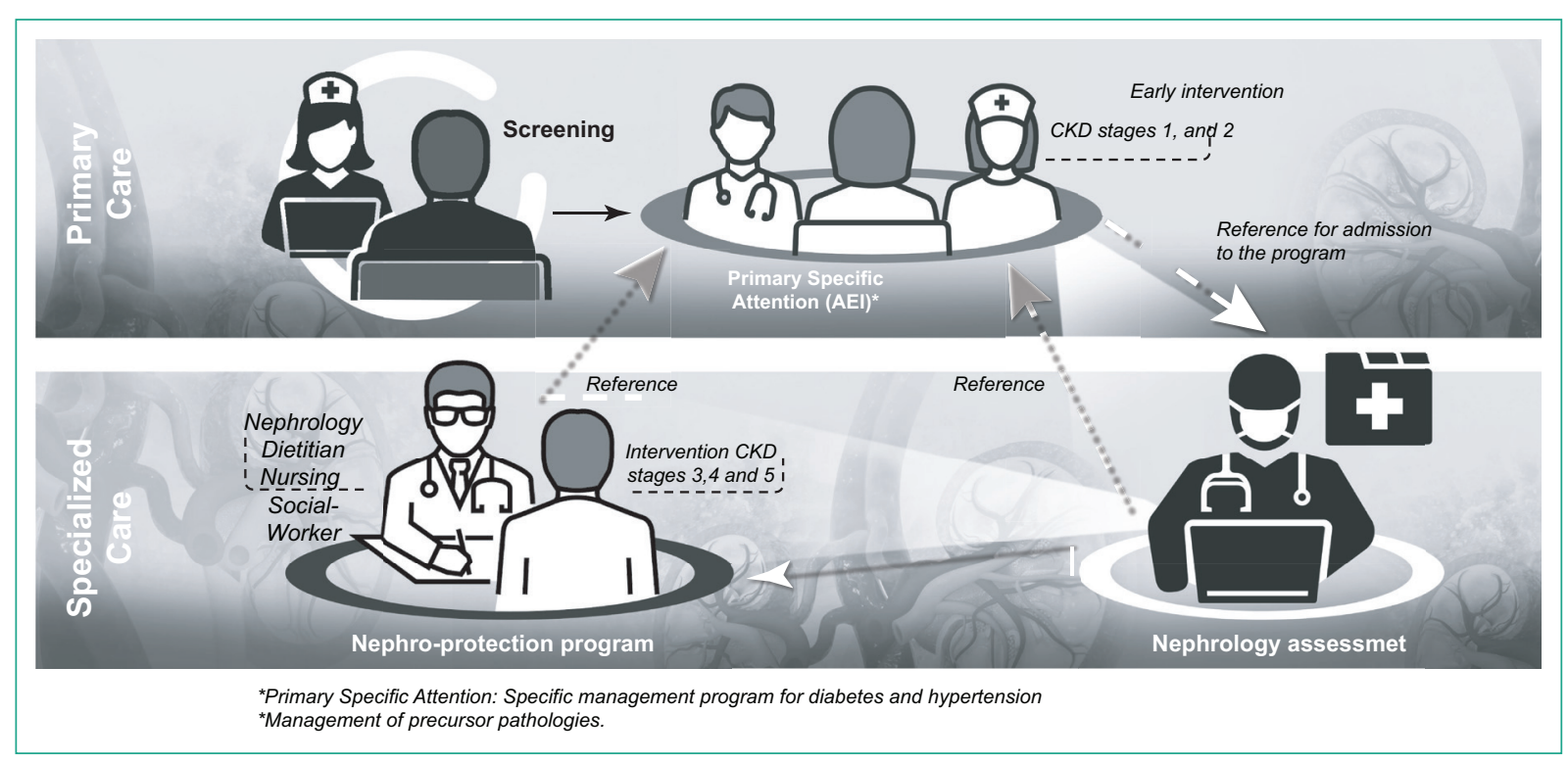

Figure 1. Prevention program. The figure represents integrated care at its primary and specialized level.

does not contain identifiable information and is an observational study; this trial was conducted following the principles of the Helsinki Declaration and Good Clinical Practices and Colombian resolution No 00843 , 1993. In addition, all patients signed the document for data protection "Habeas data" provided by the laws of Colombia.

\section{Data source and analysis}

\section{Baseline PATIENT CHARACTERISTICS}

Baseline demographic and clinic variables including age, sex, socioeconomic status, education level, CKD cause, history of diabetes mellitus, history of cardiovascular disease, history of cerebrovascular disease, history of obesity, uncontrolled blood pressure (defined as systolic $>140 \mathrm{mmHg}$ and/or diastolic $>90 \mathrm{~mm} \mathrm{Hg}$ for each period observed), eGFR-CKD EPI, serum albumin, hemoglobin, and albuminuria/creatinuria ratio. All data were retrospectively collected from patients' electronic medical records Versia ${ }^{\circledR}$.

\section{StUdY OUTCOMES}

The outcomes were: dialysis initiation, arrival to CKD stage G5 without KRT, dropout of the program, hospitalization, and mortality. During follow-up, patients were censored for events such as kidney transplant, suspended from the program, improve to CKD stage G2 or
G1, and change of program. Time elapsed between the start of follow-up and the moment of censorship was included in estimating the frequency of outcomes.

\section{PreVention program}

Integrated health care networks were established to coordinate and improve the identification and intervention of CKD patients. Compensar ${ }^{\circledR}$ and Baxter Renal Care Service (RCS) ${ }^{\circledR}$ integrated their primary and specialized levels of health care ${ }^{19}$.

In the first level, general practitioners and family doctors identified CKD patients, focused on high-risk groups as diabetics or hypertensives. A screening protocol was put in place to capture all the patients with CKD stages G3, G4, or G5, who were referred for specialized care (Fig. 1).

At the second level of care, a multidisciplinary team made up of a nephrologist, nurse, nutritionist, and a social worker was in charge of confirming the diagnosis and intervening on the patient to reduce the rate of progression of CKD, control his comorbidities and prepare them for a possible future KRT (Fig. 1).

The program's cornerstone was the educational component aimed at ensuring that the patient knew their disease very well, the factors that may condition an increase in the speed of progression of their disorder, and aspects of future KRT.

Patients were identified with a card at the beginning of the program. The educational component is supported 
by an information booklet with aspects of interest related to CKD, diet adjustments in this disease, general recommendations to follow, and the issue of shared decisions regarding an eventual requirement for KRT. The educational intervention is carried out directly with the patient, workshops, and group educational events. The multidisciplinary team's intervention focuses on slowing down the rate of progression for which the indicated pharmacological treatment, diet, monitoring of eGFR and proteinuria is established, and avoiding additional events or toxins that can affect the already deteriorated renal function.

The frequency of this comprehensive care was quarterly for patients with CKD stage G3 and monthly for those with stages $\mathrm{G} 4$. The program was systematically and periodically monitored through indicators that allow population management ${ }^{19}$.

\section{Statistical Analysis}

We used descriptive statistics to report the population characteristics according to the distribution of variables. The patients were classified according to the stability, increase or decrease of eGFR measured in $\mathrm{ml} / \mathrm{min} / 1.73 \mathrm{~m}^{2} /$ year, taking the definition presented by Cortinovis et al. ${ }^{20}$. We estimated the start dialysis incidence rate as episodes per patient-year and 95\% confidence intervals $(\mathrm{Cl})$ based on Kaplan-Meier method. Imputation procedure was performed for serum albumin from a mixed-effects model with random intercept as a function of period. A mixed-effects model was adjusted to estimate the progression of the glomerular filtration rate in the periods defined in 4-month periods, according to the diagnosis of diabetes. A random intercept model was adjusted based on history of diabetes, period, and interaction between these two variables. The estimation of the model coefficients, both fixed and random, their corresponding $p$-value, and their $95 \% \mathrm{Cl}$ were obtained.

An Extended Cox model was adjusted for the time to start KRT, taking as independent variables the fixed variables: age at entry to the program, history of diabetes mellitus, eGFR at the beginning of the program, and smoking; and time-dependent variables: lack of control of blood pressure, consumption of angiotensin II receptor blockers, serum albumin, and consumption of angiotensin-converting enzyme inhibitors.

The model was adjusted taking periods of 4 months and a lag of one period (lag = 1). We used the Wald statistic to evaluate whether a set of variables could be removed from the complete model. The estimation of the coefficients of the final model and its corresponding $\mathrm{p}$-value, the estimation of the hazard ratio $(\mathrm{HR})$, and its $95 \% \mathrm{Cl}$ were estimated. STATA $14^{\circledR}$ (StataCorp LLC, College Station, Texas) and $\mathrm{R}$ program were used in the statistical analyses.

\section{Results}

A total of 1448 patients were included in the analysis; the mean age was 63.6 years; the most frequent CKD cause was hypertension with $48.2 \%$ of cases; obesity was present in $22.1 \%$ of patients at the cohort's inception, the mean eGFR at this point was $49.6 \mathrm{ml} / \mathrm{min} / 1.73 \mathrm{~m}^{2}$, and the follow-up time median was 1.9 years $(95 \% \mathrm{Cl}$ : 1.2-2.0), table 1; details of the patient's flow within the study are presented in figure 2 .

We found that $27.7 \%$ had a fast progression (declining of eGFR $\geq-1.2 \mathrm{ml} / \mathrm{min} / 1.73 \mathrm{~m}^{2} /$ year), $11 \%$ had a slow progression (declining of eGFR -1.2-0.0 ml/ $\mathrm{min} / 1.73 \mathrm{~m}^{2} /$ year), and $61.3 \%$ had a regression (increasing of eGFR per-year) (Table 2).

All patients contributed 2354 person-years of follow-up and 49 dialysis initiation events were observed, which represents an incidence rate of dialysis initiation of 2.1 events per 100 patients-year (95\% Cl: 1.5-2.7), 63 patients get to CKD grade 5 events, representing a rate of 2.7 events per 100 patients-year $(95 \% \mathrm{Cl}$ : 2.0$3.4)$; this represents a total 305 dialysis-free months (95\% Cl: 200 to 409 ), median 4.8 months (SD $=6.5$ ), and the rate of program's dropout was 2.8 events per 100 patients-year, (95\% Cl: 2.1-3.5) (Table 3).

Regarding the results found in the mixed model for progression, the mean eGFR value for the population without diabetes at the beginning of the program was $48.8 \mathrm{ml} / \mathrm{min} / 1.73 \mathrm{~m}^{2}$ and a slight increase in eGFR per 4 months period of $0.38 \mathrm{ml} / \mathrm{min} / 1.73 \mathrm{~m}^{2}$ was observed. In the diabetic patients, the mean eGFR value at the beginning of the program was $46.3 \mathrm{ml} / \mathrm{min} / 1.73 \mathrm{~m}^{2}$; and the eGFR decreased $-0.33 \mathrm{ml} / \mathrm{min} / 1.73 \mathrm{~m}^{2} / 4$ months period (Fig. 3).

At the day 1 of dialysis, $51 \%$ of patients started with peritoneal dialysis (PD), $44.9 \%$ of patients had a vascular catheter as their first access; also $51 \%$ of the patients required hospitalization peri-initiation of dialysis therapy, and the mean eGFR at start dialysis was $9.3 \mathrm{ml} / \mathrm{min} / 1.73 \mathrm{~m}^{2}$ (Table 4).

Table 5 reports a summary of the extended Cox model for variables associated with the outcome time until dialysis, where the variables being diabetic $(p<0.01)$ and having poorly controlled hypertension $(p<0.01)$ stands out as a significant risk for the outcome. 
Table 1. Baseline characteristics of the study population

\begin{tabular}{|c|c|}
\hline Characteristics & $\mathrm{n}=1448$ \\
\hline Age, mean (SD) & $63.6(11.0)$ \\
\hline $\begin{array}{l}\text { Sex; } n(\%) \\
\text { Male } \\
\text { Female }\end{array}$ & $\begin{array}{l}785(54.2) \\
663(45.8)\end{array}$ \\
\hline $\begin{array}{l}\text { Socioeconomic status; } \mathrm{n}(\%) \\
\quad 1 \text { (Low) } \\
2 \\
3 \\
4 \\
6 \text { (High) }\end{array}$ & $\begin{array}{c}272(21.7) \\
91(7.3) \\
859(68.6) \\
30(2.4) \\
1(0.1)\end{array}$ \\
\hline $\begin{array}{l}\text { School-level; n (\%) } \\
\text { Illiteracy } \\
\text { Read and write } \\
\text { Elementary } \\
\text { High School/Technical } \\
\text { University }\end{array}$ & $\begin{array}{c}18(1.2) \\
39(2.7) \\
181(12.5) \\
1135(78.4) \\
75(5.2)\end{array}$ \\
\hline $\begin{array}{l}\text { CKD cause; } \mathrm{n}(\%) \\
\text { Hypertension } \\
\text { Diabetes } \\
\text { Urinary tract obstruction } \\
\text { Polycystic kidney disease } \\
\text { Chronic interstitial tubulonephritis } \\
\text { Glomerulonephritis } \\
\text { Chronic pyelonephritis } \\
\text { Unknown } \\
\text { Other }\end{array}$ & $\begin{array}{c}698(48.2) \\
232(16.0) \\
116(8.0) \\
18(1.2) \\
4(0.3) \\
61(4.2) \\
3(0.2) \\
143(9.9) \\
173(12.0)\end{array}$ \\
\hline History of cardiovascular disease; $\mathrm{n}(\%)$ & $142(9.8)$ \\
\hline History of cerebrovascular disease; $n(\%)$ & $28(1.9)$ \\
\hline $\begin{array}{l}\text { Tobacco smoking history; } \mathrm{n}(\%) \\
\text { Obesity BMI } \geq 30 ; \mathrm{n}(\%) \\
\text { Uncontrolled of blood pressure; } \mathrm{n}(\%)^{\mathrm{a}} \\
\text { eGFR -CKDEpi ml/min/1.73 } \mathrm{m}^{2} ; \text { median (IQR) }\end{array}$ & $\begin{array}{c}275(19.0) \\
320(22.1) \\
208(14.3) \\
49.6(42.2,54,7)\end{array}$ \\
\hline Stages G3 (eGFR 30 to $59 \mathrm{ml} / \mathrm{min} / 1.73 \mathrm{~m}^{2} ; \mathrm{n}(\%)$ & $1348(93.1)$ \\
\hline $\begin{array}{l}\text { Stages G4 (eGFR } 15 \text { to } 29 \mathrm{ml} / \mathrm{min} / 1.73 \mathrm{~m}^{2} ; \mathrm{n}(\%) \\
\text { Serum albumin } \mathrm{g} / \mathrm{dL} \text {; mean (SD) } \\
\text { Hemoglobin } \mathrm{g} / \mathrm{dL} \text {; mean (SD) }\end{array}$ & $\begin{array}{l}100(6.9) \\
4.3(0.3) \\
14.7(1.9)\end{array}$ \\
\hline $\begin{array}{l}\text { Albuminuria/creatinuria ratio } \mathrm{mg} / \mathrm{G} ; \mathrm{n}(\%) \\
<30 \mathrm{mg} / \mathrm{g} \\
30-300 \mathrm{mg} / \mathrm{g} \\
>300 \mathrm{mg} / \mathrm{g} \\
\text { Data not available }\end{array}$ & $\begin{array}{l}507(35.0) \\
154(10.7) \\
180(12.4) \\
607(41.9)\end{array}$ \\
\hline $\begin{array}{l}\text { Consumption of angiotensin II receptor } \\
\text { blockers; } n(\%)\end{array}$ & $38(2.6)$ \\
\hline Consumption of ACE inhibitors; $n(\%)$ & $170(11.7)$ \\
\hline Follow-up time, years, median (IQR) & $1.9(1.2,2.0)$ \\
\hline
\end{tabular}

SD: standard deviation; CKD: chronic Kidney Disease; BMI: body mass index; eGFR: estimated glomerular filtration rate; IQR: interquartile range;

ACE: angiotensin-converting enzyme inhibitors; a: systolic blood pressure

$\geq 140 \mathrm{mmHg}$ and/or diastolic blood pressure $\geq 90 \mathrm{mmHg}$; b: estimation formula CKD-EPI ml/min/1.73 $\mathrm{m}^{2}$.

A total of 484 hospitalizations were observed during the follow-up; $21.3 \%$ of the patients had one or more hospitalization events. The hospitalization rate was 20

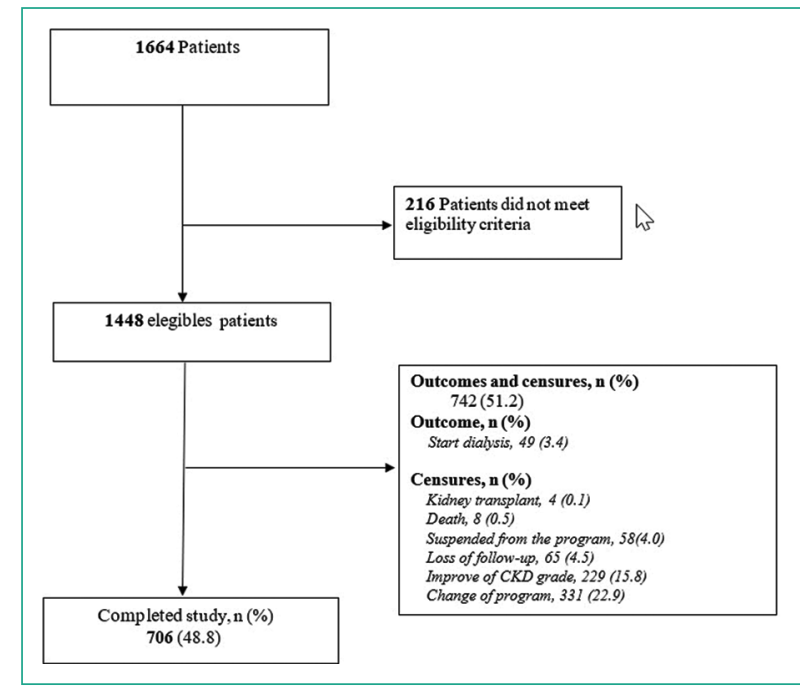

Figure 2. Flowchart of patients in the study. The diagram shows the flow of patients in the study. Of 1664 originally recruited patients, 216 did not meet the eligibility criteria and 49 patients start dialysis.

events per 100 patient-year (95\% Cl: 18-22). A total of 2988 days of stay were recorded, representing a stay rate of 1.3 hospital days/patient/year $(95 \% \mathrm{Cl}$ : $1.22-$ 1.31) and the median stay was 4 days $(I Q R=2,8)$.

\section{Discussion}

The prevention of CKD is mandatory within health policies for the control of non-communicable diseas$\mathrm{es}^{21}$. Regarding CKD secondary prevention programs, initiation of dialysis and adherence to the program are essential outcomes ${ }^{22,23}$. In this sense, our study conducted in a CKD large preventive cohort shows a dialysis initiation rate of around 2 events per 100 patient-years. We also observed a rate of dropout of the program of 2.8 events per 100 patient-years. This rate could be at least partially related to a follow-up time that was only around 2 years, which is a short period for a proportion of this population that begins follow-up in the early stages of this disease; in other words, studies with a longer follow-up time would allow confirming these findings.

The median eGFR progression of approximately +1.0 mil $/ \mathrm{min} / 1.73 \mathrm{~m}^{2} /$ year for non-diabetic population, showing that patients of this program behave in a stable manner in terms of maintaining eGFR. This CKD progression's velocity is similar to others found in the literature ${ }^{24}$; however, it should be observed that there is significant variability of results in this regard, probably influenced by the type of population studied ${ }^{6,12,13}$. We 
Nefro Latinoam. 2021;18

Table 2. Characterization of the population according to the progression or regression of the CKD defined by eGFR

\begin{tabular}{|l|c|c|c|c|}
\hline Characteristics & Fast progression & Slow progression & Regression & Total \\
\hline Diabetic, $\mathrm{n}(\%)$ & $157(41.9)$ & $39(10.4)$ & $179(47.7)$ & $375(100)$ \\
\hline Non-diabetic, $\mathrm{n}(\%)$ & $244(22.7)$ & $120(11.2)$ & $709(66.1)$ & $1073(100)$ \\
\hline Age: $18-64$ years, $\mathrm{n}(\%)$ & $219(31.3)$ & $85(12.2)$ & $395(56.5)$ & $699(100)$ \\
\hline$\geq 65$ years, $\mathrm{n}(\%)$ & $182(24.3)$ & $74(9.9)$ & $493(65.8)$ & $749(100)$ \\
\hline Male, $\mathrm{n}(\%)$ & $232(29.6)$ & $95(12.1)$ & $458(58.3)$ & $785(100)$ \\
\hline Female, $\mathrm{n}(\%)$ & $169(25.5)$ & $64(9.6)$ & $430(64.9)$ & $663(100)$ \\
\hline Full sample, $\mathrm{n}(\%)$ & $401(27.7)$ & $159(11.0)$ & $888(61.3)$ & $1448(100)$ \\
\hline
\end{tabular}

Fast progression: declining of eGFR $\geq-1.2 \mathrm{~m} / / \mathrm{min} / 1.73 \mathrm{~m}^{2} / \mathrm{year}$; slow progression: declining of eGFR <-1.2-0 m//min $/ 1.73 \mathrm{~m}^{2} /$ year; regression: increasing of eGFR per year.

Table 3. Main outcomes of the prevention program

\begin{tabular}{|c|c|c|c|}
\hline Outcomes & Person-years & Events & Rate $[95 \% \text { Cl }]^{\mathrm{a}}$ \\
\hline $\begin{array}{l}\text { Dialysis initiation: } \\
\text { slow progression }\end{array}$ & 281 & 4 & $1.4[0.5,3.8]^{\mathrm{a}}$ \\
\hline Fast progression & 698 & 42 & $6.0[4.4,8.1]$ \\
\hline Regression & 1375 & 3 & $0.2[0.1,0.7]$ \\
\hline Total & 2354 & 49 & $2.1[1.5,2.7]$ \\
\hline Get to CKD grade 5 & 2354 & 63 & $2.7[2.0,3.4]$ \\
\hline Program's dropout & 2354 & 65 & $2.8[2.1,3.5]$ \\
\hline Mortality & 2354 & 8 & $0.34[0.14,0.67]$ \\
\hline
\end{tabular}

hypothesized that the result of progression might be related to the fact that a significant proportion of patients fall under slow progressors, with an over-representation of old and hypertensive patients. On the other hand, these results may be associated with the finding that a substantial number of patients entered the CKD prevention program relatively early in their disease course, with a median eGFR at baseline of about $50 \mathrm{ml} / \mathrm{min} / 1.73 \mathrm{~m}^{2}$. Other studies confirm the importance of early detection of CKD and the benefits of systematic and multidisciplinary intervention with secondary prevention programs ${ }^{25,26}$.

Another reason that can explain the previous result is related to the systematic, multidisciplinary, and early intervention, precisely aimed at slowing down the velocity of progression. Furthermore, other studies report different progression characteristics and probabilities ${ }^{20,27}$, whit a significant proportion of patients having
Table 4. Baseline characteristics of the population starting dialysis

\begin{tabular}{|l|c|}
\hline Start dialysis characteristics & $\mathrm{n}=49$ \\
\hline Age, mean (SD) years & $55.2(13.1)$ \\
\hline Sex: male, $\mathrm{n}(\%)$ & $31(63.3)$ \\
\hline Diabetes history, $\mathrm{n}(\%)$ & $21(42.8)$ \\
\hline Hypertension history, $\mathrm{n}(\%)$ & $42(85.7)$ \\
\hline Body mass index mean (SD) & $26.8(4.5)$ \\
\hline eGFR on beginning, median (IOR) ml/min/1.73 m² & $9.3(7.2,10.9)$ \\
\hline Hemodialysis, $\mathrm{n}(\%)$ & $25(51.0)$ \\
\hline Dialysis peritoneal, $\mathrm{n}(\%)$ & $24(49.0)$ \\
\hline Dialysis access, $\mathrm{n}(\%)$ & \\
\hline $\begin{array}{l}\text { Arteriovenous fistula } \\
\text { Vascular catheter }\end{array}$ & $3(6.1)$ \\
\hline Peritoneal catheter & $22(44.9)$ \\
\hline Hospitalization requirement, $\mathrm{n}(\%)^{\mathrm{a}}$ & $24(49.0)$ \\
\hline Serum albumin g/dL median (IOR) & $25(51.0)$ \\
\hline Hemoglobin g/dL median (IOR) & $4.1(3.5,4.8)$ \\
\hline
\end{tabular}

a: admission 3 days before or 3 days after the dialysis start; SD: standard deviation; eGFR: estimated glomerular filtration rate; IQR: interquartile range.

CKD progression that tends toward remission or regression.

From our perspective, being able to estimate the frequency of hospitalization events in the pre-dialysis stage is essential for health policymakers and health economic analysis and constitutes one of the strengths of our study. This estimator of 0.2 events per patient-year is low compared to the population on dialysis, and it tells us about the significant impact of KF on morbidity outcomes ${ }^{28}$. 


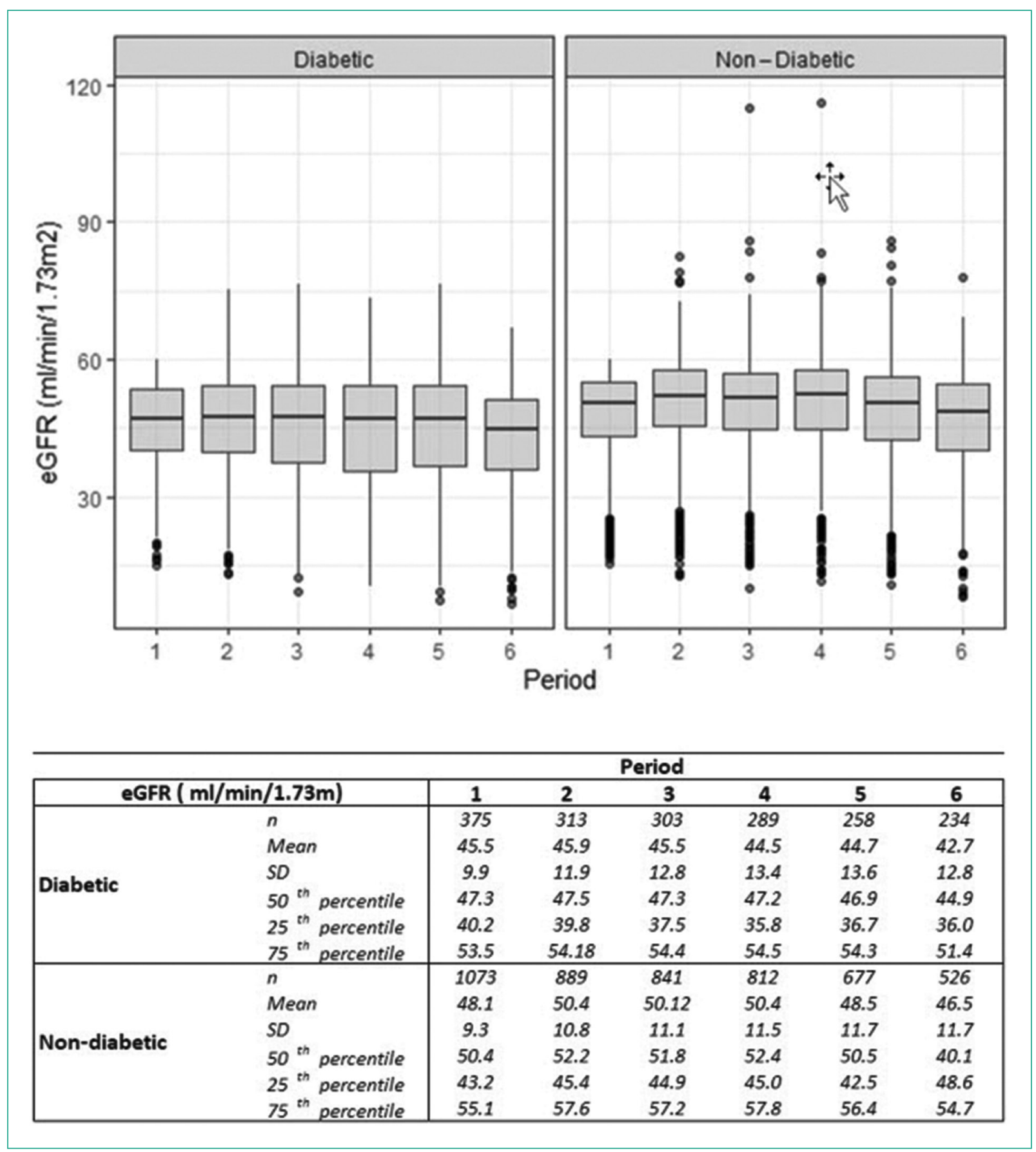

Figure 3. Behavior of estimated glomerular filtration rate over time. eGFR: estimation formula CKD-EPI ml/min/1.73 $\mathrm{m}^{2}$; period: months.

As mentioned above, this population showed a high adherence to the preventive program; which is achieved with a continuous effort in education to the patient and their family and close monitoring of consult appointments to ensure permanence; as already mentioned, this result must be confirmed in studies with a longer follow-up time.
The extended Cox model showed us that being diabetic and having no blood pressure control are risk factors for CKD progression to KF.

In turn, early detection of CKD (higher eGFR at the beginning), adequate serum albumin levels, and age are protective factors for the same outcome. Interesting is the fact that for each year of age, there is a protective 
Table 5. Extended Cox model for time to start dialysis

\begin{tabular}{|l|c|c|c|}
\hline Variables & Hazard ratio & $95 \% \mathrm{Cl}$ & $\mathrm{p}$-value \\
\hline Age; years & 0.96 & $0.94-0.98$ & $<0.001$ \\
\hline Diabetes: yes & 2.74 & $1.46-5.12$ & $<0.001$ \\
\hline eGFR; ml/min/1.73 m² & 0.90 & $0.88-0.93$ & $<0.001$ \\
\hline $\begin{array}{l}\text { Uncontrolled of blood } \\
\text { pressure* }\end{array}$ & 3.97 & $2.19-7.21$ & $<0.001$ \\
\hline Serum albumin; g/dL* & 0.16 & $0.09-0.27$ & $<0.001$ \\
\hline
\end{tabular}

eGFR: estimated glomerular filtration rate; Cl: confidence interval; *time-dependent variables

factor for the outcome time to dialysis; it could be related to a significant proportion of elderly and hypertensive patients and that could fall under the subgroup of low-progressors ${ }^{29}$.

The high proportion of patients who start KRT with $P D$ is striking, a fact that could be related to a planned start of dialysis therapy; however, the low proportion of patients who start hemodialysis with arteriovenous fistula is also notable, which undoubtedly constitutes an opportunity to improve this program.

As for the strengths of this study, we can mention that it includes data originating from an established CKD prevention program in a large population of patients with standardized interventions/assessments.

Study limitations include lack of data on micro-albuminuria during the follow-up, which lead to the inability to analyze this critical marker of progression; otherwise, the CKD progression estimation was done below the linear paradigm despite a proportion of CKD patients follow a process that is non-linear ${ }^{17}$. Furthermore, this study presents data from a single cohort, so its results cannot be contrasted with other types of interventions; however, since various measures of frequency of outcomes, progression, and risk models are presented, the information is useful for various actors in the health systems.

\section{Conclusion}

The present study in a substantial population of patients in a CKD preventive program establishes the frequency of significant interest events, such as incidence rates of dialysis initiation, program dropout, and hospitalization events; diabetes and poor blood pressure control are risk factors for a more rapid progression to dialysis. These secondary prevention programs are of great importance to control the burden of CKD on populations.

\section{Funding}

Mr. Sanabria is a full-time employee of Baxter Renal Care Services-Latin America, Bogotá, Colombia. Ms. Espinosa and Ms. Quintero are full-time employees of Compensar EPS Bogota, Ms. Ronderos y Ms. Perea are full-time employees of Baxter Renal Care Services Colombia, Clinica de Salud Renal, Bogota, Ms. Vesga is a full-time employee of Renal Therapy Services-Colombia, Bogotá, and Ms. Corzo is a full-time employee of Baxter Renal Care Services Colombia, Instituto Nacional del Riñon, Bogota. Mr. Rincón, Ms. Rodriguez, and Ms. Herrera have received an honorarium for a consultancy from Baxter Renal Care Services Colombia.

\section{Acknowledgments}

The authors wish to express their gratitude to all the patients and clinical teams who participated in the study.

\section{Conflicts of interest}

The authors declare that does not exist conflicts of interest.

\section{Ethical disclosures}

Protection of human and animal subjects. The authors declare that no experiments were performed on humans or animals for this study.

Confidentiality of data. The authors declare that they have followed the protocols of their work center on the publication of patient data.

Right to privacy and informed consent. The authors declare that no patient data appear in this article.

\section{References}

1. Levey AS, Coresh J. Chronic kidney disease. Lancet. 2012;379:165-80. 2. Brenner BM. Retarding the progression of renal disease. Kidney Int. 2003;64:370-8.

3. Kidney Disease: improving Global Outcomes (KDIGO) CKD Work Group. KDIGO 2012 clinical practice guideline for the evaluation and management of chronic kidney disease. Kidney Int Suppl. 2013;3:1-150.

4. Levey AS, Eckardt KU, Dorman NM, Christiansen SL, Hoorn EJ, Ingelfinger JR, et al. Nomenclature for kidney function and disease: report of kidney disease: improving global outcomes (KDIGO) consensus conference. Kidney Int. 2020;97:1117-29.

5. Nugent RA, Fathima SF, Feigl AB, Chyung D. The burden of chronic kidney disease on developing nations: a $21^{\text {st }}$ century challenge in global health. Nephron Clin Pract. 2011;118:269-77. 
6. Muntner P. Longitudinal measurements of renal function. Semin Nephrol. 2009;29:650-7.

7. Appel L, Wright JT Jr., Greene T, Kusek JW, Lewis JB, Wang X, et al. Long-term effects of renin-angiotensin system-blocking therapy and a low blood pressure goal on progression of hypertensive chronic kidney disease in African Americans. Arch Intern Med. 2008;168:832-9

8. Klahr S, Levey AS, Beck GJ, Caggiula AW, Hunsicker L, Kusek JW, et al. The effects of dietary restriction and blood-pressure control on the progression of chronic renal disease. N Engl J Med. 1994;330:877-84.

9. Lazarus JM, Bourgoignie JJ, Buckalew VM, Greene T, Levey AS Milas NC, et al. Achievement and safety of a low blood pressure goal in chronic renal disease: the modification of diet in renal disease study group. Hypertension. 1997;29:641-50.

10. Hu B, Gadegbeku C, Lipkowitz MS, Rostand S, Lewis J, Wright JT, et al. Kidney function can improve in patients with hypertensive CKD. J Am Soc Nephrol. 2012;23:706-13.

11. Sikaneta T, Abdolell M, Taskapan H, Roscoe J, Fung J, Nagai G, et al Variability in CKD stage in outpatients followed in two large renal clinics. Int Urol Nephrol. 2012;44:1461-6.

12. Lee D, Levin A, Roger SD, McMahon LP. Longitudinal analysis of performance of estimated glomerular filtration rate as renal function declines in chronic kidney disease. Nephrol Dial Transplant. 2009;24:109-16.

13. Li L, Astor B, Lewis J, Hu B, Appel LJ, Lipkowitz MS, et al. Longitudinal Progression trajectory of GFR among patients with CKD. Am J Kidney Dis. 2012;59:504-12.

14. Caravaca-Fontán F, Azevedo L, Luna E, Caravaca F. Patterns of progression of chronic kidney disease at later stages. Clin Kidney J. 2018;11:246-53.

15. Tangri N, Stevens LA, Griffith J, Tighiouart H, Djurdjev O, Naimark D, et al. A predictive model for progression of chronic kidney disease to kidney failure. JAMA. 2011;305:1553-9.

16. Lee MJ, Park JH, Moon YR, Jo SY, Yoon D, Park RW, et al. Can we predict when to start renal replacement therapy in patients with chronic kidney disease using 6 months of clinical data? PLoS One. 2018:13:e0204586.

17. Onuigbo MA, Agbasi N. Chronic kidney disease prediction is an inexact science: the concept of "progressors" and "nonprogressors". World J Nephrol. 2014;3:31-49.
18. Kadatz MJ, Lee ES, Levin A. Predicting progression in CKD: perspectives and precautions. Am J Kidney Dis. 2016;67:779-86.

19. Rico A, Perea D, Garizabalo O, Sanabria M, Vesga J, Ronderos I, et al. Programa de prevención de la enfermedad renal crónica basado en redes integradas de servicios en Colombia. Rev Salud Pública. 2017;19:171-6.

20. Cortinovis M, Ruggenenti P, Remuzzi G. Progression, remission and regression of chronic renal disease. Nephron. 2016;134:20-4.

21. Couser WG, Remuzzi G, Mendis S, Tonelli M. The contribution of chronic kidney disease to the global burden of noncommunicable diseases. Kidney Int. 2011;80:1258-70.

22. Levey A, Stevens LA, Coresh J. Conceptual model of CKD: applications and implications. Am J Kidney Dis. 2009;53:S4-16.

23. Dodd R, Palagyi A, Guild L, Jha V, Jan S. The impact of out-of-pocket costs on treatment commencement and adherence in chronic kidney disease: a systematic review. Health Policy Plan. 2018;33:1047-54.

24. Eriksen B, Ingebretsen OC. The progression of chronic kidney disease: a 10-year population-based study of the effect of gender and age. Kidney Int. 2006;69:375-82.

25. Acuña L, Sanchez P, Soler LA, Alvis LF. Enfermedad renal crónica en Colombia: prioridad para la gestión de riesgo. Rev Panam Salud Pública. 2016;40:16-22.

26. Yepes Delgado CE, Pérez Dávila S, Montoya Jaramillo M, Orrego Orozco BE. Progreso de estadio y requerimiento de terapia de reemplazo renal en un programa de protección renal en Colombia. Estudio de cohorte. Nefrología. 2017;37:330-7.

27. Li L, Astor BC, Lewis J, Hu B, Appel LJ, Lipkowitz MS, et al. Longitudinal progression trajectory of GFR among patients with CKD. Am J Kidney Dis. 2012;59:504-12

28. United States Renal Data System. 2020 USRDS Annual Data Report: epidemiology of Kidney Disease in the United States. Bethesda, MD: National Institutes of Health, National Institute of Diabetes and Digestive and Kidney Diseases; 2020.

29. Agarwal A, Haddad N, Hebert LA. Progression of kidney disease: diagnosis and management. In: Molony DA, Craig JC, editors. Evidence-based Nephrology. $1^{\text {st }}$ ed. Hoboken, NJ: John Wiley and Sons; 2008. p. 311-22. 